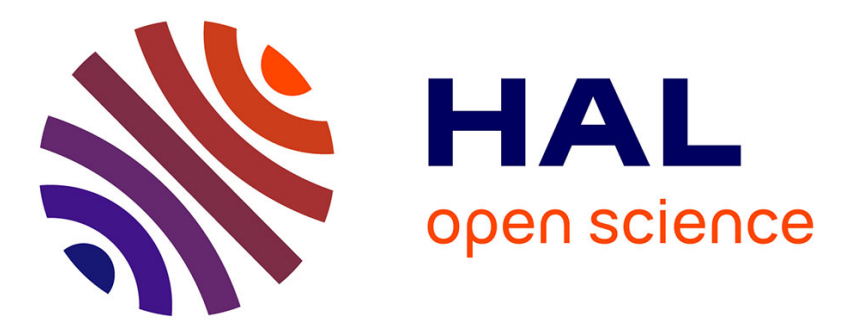

\title{
Deposition and dielectric characterization of strontium and tantalum-based oxide and oxynitride perovskite thin films
}

\author{
S. Jacq, C. Le Paven, L. Le Gendre, Ratiba Benzerga, François Cheviré, \\ Franck Tessier, A. Sharaiha
}

\section{To cite this version:}

S. Jacq, C. Le Paven, L. Le Gendre, Ratiba Benzerga, François Cheviré, et al.. Deposition and dielectric characterization of strontium and tantalum-based oxide and oxynitride perovskite thin films. Solid State Sciences, 2016, 54, pp.22-29. 10.1016/j.solidstatesciences.2015.12.010 hal-01254806

\section{HAL Id: hal-01254806 https://hal-univ-rennes1.archives-ouvertes.fr/hal-01254806}

Submitted on 4 Feb 2016

HAL is a multi-disciplinary open access archive for the deposit and dissemination of scientific research documents, whether they are published or not. The documents may come from teaching and research institutions in France or abroad, or from public or private research centers.
L'archive ouverte pluridisciplinaire HAL, est destinée au dépôt et à la diffusion de documents scientifiques de niveau recherche, publiés ou non, émanant des établissements d'enseignement et de recherche français ou étrangers, des laboratoires publics ou privés. 


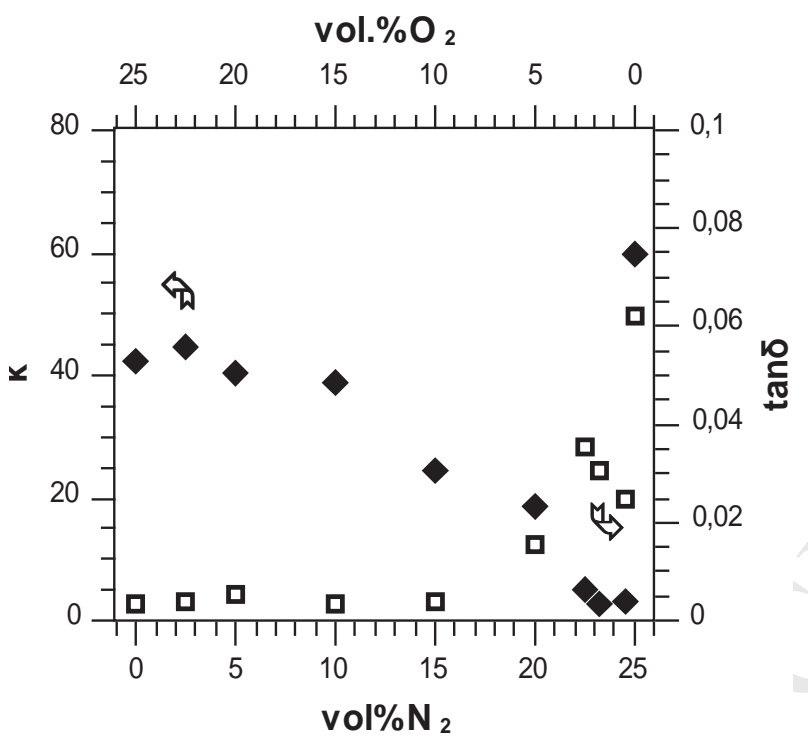

\section{Graphical Abstract}

Evolution of the permittivity $\kappa$ and loss tangent $\tan \delta(@ 1 \mathrm{kHz})$ of

$\left(\mathrm{Sr}_{0.99} \mathrm{La}_{0.01}\right)_{2}\left(\mathrm{Ta}_{0.99} \mathrm{Ti}_{0.01}\right)_{2} \mathrm{O}_{7}$ and $\left(\mathrm{Sr}_{0.99} \mathrm{La}_{0.01}\right)\left(\mathrm{Ta}_{0.99} \mathrm{Ti}_{0.01}\right) \mathrm{O}_{2} \mathrm{~N}$ thin films as a function of the dinitrogen and dioxygen percentages in the reactive sputtering plasma used for the deposition. 
Deposition and dielectric characterization of strontium and tantalum-based oxide and oxynitride perovskite thin films

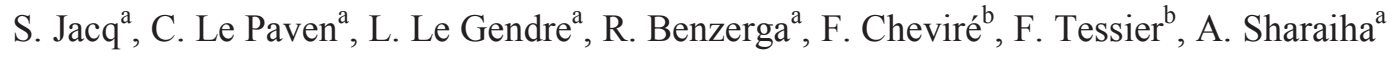 \\ ${ }^{a}$ Institut d'Electronique et de Télécommunications de Rennes (IETR), Equipe Matériaux \\ Fonctionnels, IUT Saint-Brieuc, Université de Rennes 1, 22000 Saint Brieuc, France. \\ ${ }^{\mathrm{b}}$ Institut des Sciences Chimiques de Rennes (ISCR), Equipe Verres et Céramiques, Université \\ de Rennes 1, 35042 Rennes, France.
}

Corresponding author: Claire Le Paven, claire.lepaven@univ-rennes1.fr, +33296609659

\begin{abstract}
We have synthesized the composition $\mathrm{x}=0.01$ of the $\left(\mathrm{Sr}_{1-\mathrm{x}} \mathrm{La}_{\mathrm{x}}\right)_{2}\left(\mathrm{Ta}_{1-\mathrm{x}} \mathrm{Ti}_{\mathrm{x}}\right)_{2} \mathrm{O}_{7}$ solid solution, mixing the ferroelectric perovskite phases $\mathrm{Sr}_{2} \mathrm{Ta}_{2} \mathrm{O}_{7}$ and $\mathrm{La}_{2} \mathrm{Ti}_{2} \mathrm{O}_{7}$. Related oxide and oxynitride materials have been produced as thin films by magnetron radio frequency sputtering. Reactive sputter deposition was conducted at $750^{\circ} \mathrm{C}$ under a 75 vol.\%(Ar) +25 vol. $\%\left(\mathrm{~N}_{2}, \mathrm{O}_{2}\right)$ mixture. An oxygen-free plasma leads to the deposition of an oxynitride film $\left(\mathrm{Sr}_{0.99} \mathrm{La}_{0.01}\right)\left(\mathrm{Ta}_{0.99} \mathrm{Ti}_{0.01}\right) \mathrm{O}_{2} \mathrm{~N}$, characterized by a band gap $\mathrm{E}_{\mathrm{g}}=2.30 \mathrm{eV}$ and a preferential (001) epitaxial growth on (001) $\mathrm{SrTiO}_{3}$ substrate. Its dielectric constant and loss tangent are respectively Epsilon' $=60($ at $1 \mathrm{kHz})$ and tanDelta $=62.510^{-3}$. In oxygen-rich conditions (vol.\% $\mathrm{N}_{2} \leq 15 \%$ ), (110) epitaxial $\left(\mathrm{Sr}_{0.99} \mathrm{La}_{0.01}\right)_{2}\left(\mathrm{Ta}_{0.99} \mathrm{Ti}_{0.01}\right)_{2} \mathrm{O}_{7}$ oxides films are deposited, associated to a larger band gap value $\left(\mathrm{E}_{\mathrm{g}}=4.55 \mathrm{eV}\right)$. The oxide films permittivity varies from 45 to 25 (at $1 \mathrm{kHz}$ ) in correlation with the decrease in crystalline orientation; measured losses are lower than $5.10^{-3}$. For $20 \leq$ vol. $\% \mathrm{~N}_{2} \leq 24.55$, the films are poorly crystallized, leading to very low permittitivities (minimum Epsilon'=3). A correlation between the dielectric losses and the presence of an oxynitride phase in the samples is highlighted.
\end{abstract}




\section{Highlights}

- Oxide and oxynitride perovskite films were deposited by magnetron sputtering

- Reactive gas containing dioxygen and dinitrogen was used

- Strontium and tantalum based $\left(\mathrm{Sr}_{0.99} \mathrm{La}_{0.01}\right)_{2}\left(\mathrm{Ta}_{0.99} \mathrm{Ti}_{0.01}\right)_{2}(\mathrm{O}, \mathrm{N})_{7}$ films were obtained

- The permittivity of the epitaxial oxide film is $42 @ 1 \mathrm{KHz}$

- The permittivity of the oriented oxynitride film is $60 @ 1 \mathrm{KHz}$

\section{Keywords}

Oxynitride; perovskite; thin films; reactive sputtering; epitaxy; dielectric.

\section{Introduction}

Among perovskite materials, many original compounds are synthesized from two parent phases, in the form of solid solutions in which the perovskite structure is maintained through cationic substitutions. The aim is to control one or more properties of the material by varying its chemical composition. Ferroelectric perovskite compounds, such as $\mathrm{PbZr}_{\mathrm{x}} \operatorname{Ti}_{1-\mathrm{x}} \mathrm{O}_{3}$ (PZT) [1], $\mathrm{Ba}_{\mathrm{x}} \mathrm{Sr}_{1-\mathrm{x}} \mathrm{TiO}_{3}$ (BST) [2] or $\mathrm{KTa}_{\mathrm{x}} \mathrm{Nb}_{1-\mathrm{x}} \mathrm{O}_{3}(\mathrm{KTN})$ [3], were thus developed with the objective of bringing their Curie temperature $\left(\mathrm{T}_{\mathrm{C}}\right)$ near room temperature, and therefore, benefit from high values of permittivity, adjustable via an external DC electrical field. The latter property can be used to make frequency agile antennas, i.e. antennas whose resonance frequency can be varied and consequently be used in different standards $[4,5]$. In miniature antennas, high permittivity perovskite thin films are positioned as the substrate of planar metallic antennas or are integrated in localized components such as capacitances [6]. Agility and miniaturization are two applications targeted for the materials presented in this paper.

$\mathrm{Sr}_{2} \mathrm{Ta}_{2} \mathrm{O}_{7}$ and $\mathrm{La}_{2} \mathrm{Ti}_{2} \mathrm{O}_{7}$, which crystallize in non-centrosymetric space groups $\mathrm{Cmc} 2_{1}$ and $\mathrm{P} 2{ }_{1}$ respectively, are perovskite ferroelectric compounds: $\mathrm{Sr}_{2} \mathrm{Ta}_{2} \mathrm{O}_{7}$ with $\mathrm{T}_{\mathrm{C}}=-107^{\circ} \mathrm{C}$ [7] 
and $\mathrm{La}_{2} \mathrm{Ti}_{2} \mathrm{O}_{7}$ with $\mathrm{T}_{\mathrm{C}}=1466^{\circ} \mathrm{C}$ [8]. Cross-substitution on the $\mathrm{A}$ and $\mathrm{B}$ sites of the prototype layered perovskite structure (PLS) $\mathrm{A}_{2} \mathrm{~B}_{2} \mathrm{O}_{7}$ would result in the solid solution $\left(\mathrm{Sr}_{1-\mathrm{x}} \mathrm{La}_{\mathrm{x}}\right)_{2}\left(\mathrm{Ta}_{1-}\right.$ $\left.{ }_{\mathrm{x}} \mathrm{Ti}_{\mathrm{x}}\right)_{2} \mathrm{O}_{7}$. Here, we have interpolated the results of Nanamatsu et al. on single crystals and ceramics [7] and determined the stoichiometry $\mathrm{x} \sim 0.01$ giving a value of $\mathrm{T}_{\mathrm{C}}$ close to room temperature. The present paper deals with the synthesis of the $\left(\mathrm{Sr}_{0.99} \mathrm{La}_{0.01}\right)_{2}\left(\mathrm{Ta}_{0.99} \mathrm{Ti}_{0.01}\right)_{2} \mathrm{O}_{7}$ (SLTTO) compound as thin films deposited by radio-frequency (rf) reactive magnetron sputtering. Moreover, we were interested in the deposition of the oxynitride $\left(\mathrm{Sr}_{0.99} \mathrm{La}_{0.01}\right)\left(\mathrm{Ta}_{0.99} \mathrm{Ti}_{0.01}\right) \mathrm{O}_{2} \mathrm{~N}$ (SLTTON) compound, where substitution occurs on the anionic sublattice because of similar values of ionic radii and electronegativity for oxygen and nitrogen $\left(\mathrm{r}_{\mathrm{O} 2-}=1.40 \AA ; \mathrm{r}_{\mathrm{N} 3-}=1.50 \AA ; \chi_{\mathrm{O}}=3.44 ; \chi_{\mathrm{N}}=3.04\right)$. Oxynitride perovkites are currently studied because of their original properties compared to their oxide parents, in particular an absorption in the visible domain leading to their use as photocatalyst in the water-splitting reactions $[9,10]$, and very high permittivities [11-14], with a potential use in agile and/or miniaturized antennas. Some reports concern these oxynitride compounds in the form of thin films [15-17].

In recent years, our research has been concerned with the deposition of oxide and oxynitride perovskite films for a use in electronic and telecommunication devices such as antennas. We have recently reported on SLTTO and SLTTON films deposited by reactive rf magnetron sputtering using $\mathrm{Ar}+\mathrm{O}_{2}$ or $\mathrm{Ar}+\mathrm{N}_{2}$ plasma, respectively [18]; the resulting films were epitaxially grown on $(001) \mathrm{MgO}$ substrates. The objective of the present study is to determine whether a mixture of the SLTTO and SLTTON compounds could be obtained using an original reactive plasma, containing $\mathrm{Ar}$ and both $\mathrm{O}_{2}$ and $\mathrm{N}_{2}$. Considering that free energies of formation of oxide compounds are lower than those of oxynitrides [19], this sort of dual-reactive medium has rarely been used up to now for the deposition of films using an oxide precursor [20]. Usually, on powders, an oxide precursor exposed to an oxidizing and 
nitriding atmosphere leads to a stable oxide, whereas an (oxy)-nitride or metallic precursor under an oxidizing and nitriding atmosphere $\left(\mathrm{O}_{2} / \mathrm{N}_{2}\right.$, for example [21]) can lead to an original oxynitride material. Here, the synthesis of the compounds as thin films, using an energetic deposition process such as sputtering deposition under dual-reactive plasma, allows us to consider that this (oxy)nitride synthesis route could be tested. Furthermore, as detailed hereafter, the mixing of SLTTO and SLTTON materials was intended in order to reduce the dielectric loss of films.

Given the very small amount $(1 \%)$ of the $\mathrm{La}_{2} \mathrm{Ti}_{2} \mathrm{O}_{7}$ material in the synthesized compounds, we will discuss our results in reference to closest compounds, $\operatorname{Sr}_{2} \mathrm{Ta}_{2} \mathrm{O}_{7}$ and $\mathrm{SrTaO}_{2} \mathrm{~N}$. For $\mathrm{Sr}_{2} \mathrm{Ta}_{2} \mathrm{O}_{7}$, permittivities from 20 to 95 have been measured on thin films [2224]; the dispersion of values can be explained by the different methods of film deposition (atomic vapor deposition, sol-gel), crystallization (amorphous, polycrystalline) and thickness of films (from 15 to $250 \mathrm{~nm}$ ). The available data on $\mathrm{SrTaO}_{2} \mathrm{~N}$ dielectric performance are scarce; on bulk samples, permittivities close to 3000 have been published by Kim et al. [11] and Hinuma et al. [12], while Masubuchi et al. reported very recently on permittivities in the range $60-200$ for ceramics obtained by high pressure densification [13]. On thin films, Oka et al. reported on $\mathrm{SrTaO}_{2} \mathrm{~N}$ films deposited by nitrogen plasma enhanced-laser ablation [25]. These films were epitaxially grown on conducting niobium-doped (001) $\mathrm{SrTiO}_{3}$ substrates and reveal permittivity around 2000 at $1 \mathrm{kHz}$ at room temperature, with dielectric losses tan $\delta$ close to $35.10^{-3}$. PFM measurements also pointed out the piezoelectric and ferroelectric behavior of films; Oka et al. proposed the material to be constituted of a relaxor ferroelectrictype matrix surrounding classical ferroelectric-type nano-domains. Besides these studies, we have also published on oxynitride $\mathrm{LaTiO}_{2} \mathrm{~N}$ (LTON) films; their permittivities are dependent on their structure and microstructure $\left(\kappa_{\text {LTON }} \sim 375-1220\right.$ [26,27]), but are always higher than the $\mathrm{La}_{2} \mathrm{Ti}_{2} \mathrm{O}_{7}$ (LTO) oxide $\left(\kappa_{\text {LTO }} \sim 60[28,29]\right)$. The drawback lies in higher losses, with tan $\delta$ 
from 0.06 to 1 for LTON thin films. For this reason, the present study does not only concern the synthesis of SLTTO oxide and SLTTON oxynitride, but the possibility of producing mixtures of phases, or even forming a $\left(\mathrm{Sr}_{0.99} \mathrm{La}_{0.01}\right)_{2}\left(\mathrm{Ta}_{0.99} \mathrm{Ti}_{0.01}\right)_{2}(\mathrm{O}, \mathrm{N})_{7}$ (SLTT) solid solution and thereby modulate the nitrogen content in films and so, reduce the dielectric losses. For that purpose, we conducted a series of deposits using an original reactive sputtering gas composed of 75 vol. $\%$ of argon and 25 vol.\% of dioxygen and dinitrogen. This paper deals with the deposition of such samples; it presents the structural and microstructural characterization of the oxide and oxynitride deposited films and gives the first results of their dielectric characterization at room temperature in the low frequency range. The study concerning the ferroelectric properties, in particular their temperature dependence, will concern other samples and will be presented in a separate paper.

\section{Materials and Methods}

Film deposition is carried out using rf reactive magnetron sputtering in a Plassys MP450S reactor using a homemade $\left(\mathrm{Sr}_{0.99}, \mathrm{La}_{0.01}\right)_{2}\left(\mathrm{Ta}_{0.99}, \mathrm{Ti}_{0.01}\right)_{2} \mathrm{O}_{7}$ target. It is obtained by uniaxial compaction of SLTTO powder synthetized by solid state chemical route from stoichiometric amounts of $\mathrm{SrCO}_{3}, \mathrm{Ta}_{2} \mathrm{O}_{5}, \mathrm{La}_{2} \mathrm{O}_{3}$ and $\mathrm{TiO}_{2}$ heated under air at $1400^{\circ} \mathrm{C}$ during $30 \mathrm{~h}$. X-ray diffraction (XRD) analysis confirms the crystallization of the powder according to a $\mathrm{Sr}_{2} \mathrm{Ta}_{2} \mathrm{O}_{7}$ analogue (see Supplementary Data 1).

A series of films is deposited using the same sputtering conditions, except the gas mixture. The plasma mixture always contains $75 \mathrm{vol} . \%$ of argon plus $25 \mathrm{vol} . \%$ dedicated to the reactive part, i.e. $\mathrm{x}$ vol. $\% \mathrm{~N}_{2}+\mathrm{y}$ vol. $\% \mathrm{O}_{2}$, with $\mathrm{x}+\mathrm{y}=25$; deposited films will be labeled as SLTT- $\mathrm{x}_{\mathrm{N} 2}-\mathrm{y}_{\mathrm{O} 2}$ (for example, SLTT-2.5 $5_{\mathrm{N} 2}-22.5_{\mathrm{O} 2}$ has been deposited under a mixture of vol. $\% \mathrm{~N}_{2}=2.5$ and vol. $\% \mathrm{O}_{2}=22.5$ ). The other deposition parameters are the following: total pressure $\mathrm{p}_{\mathrm{T}}=40 \mathrm{mTorr}$; $\mathrm{rf}$ power $\mathrm{P}_{\mathrm{rf}}=90 \mathrm{~W}\left(2.04 \mathrm{~W} / \mathrm{cm}^{2}\right)$; substrate temperature $\mathrm{T}_{\mathrm{S}}=750^{\circ} \mathrm{C}$ 
and target-substrate distance $d=5 \mathrm{~cm}$. Before deposition, a pre-sputtering of the target is performed during 100 min under the same gas mixture than deposition. The films are cooled under the same gas mixture than deposition; no post-annealing is performed.

Two kinds of single-crystalline substrates are used: (001) $\mathrm{MgO}$ and (001) $\mathrm{Nb}: \mathrm{SrTiO}_{3}$. The MgO substrate is used to determine the band-gap of the film from UV-visible spectra, while conducting $\mathrm{Nb}(1.4 \%): \mathrm{SrTiO}_{3}$ is preferred to make Metal - Insulating - Metal (MIM) structures for the dielectric measurements.

During deposition, the plasma is monitored by Optical Emission Spectroscopy (OES) using an Ocean Optics HR4000 monochromator, with the position of the optical fiber kept constant from one experiment to another. The emissions of Ar and $\mathrm{N}_{2}$ are followed at $750.4 \mathrm{~nm}\left(2 \mathrm{p}_{1} \rightarrow 1 \mathrm{~s}_{2}\right)$ [30] and $357.0 \mathrm{~nm}\left(\mathrm{C}^{3} \Pi_{\mathrm{u}} \rightarrow \mathrm{B}^{3} \Pi_{\mathrm{g}}\right)$ [31] respectively. In order to decrease the effect of the variation of the electron temperature, the $\mathrm{N}_{2}$ band intensity is divided by the one of the Ar line.

Thickness of layers is measured by Scanning Electron Microscope (SEM) crosssectional view, using a JEOL 5440 SEM; error on thickness value is estimated as being lower than $20 \mathrm{~nm}$. The chemical composition of samples is determined by semi-quantitative Energy Dispersive Spectrometry (EDS) in a JEOL5440 SEM operating at $20 \mathrm{kV}$; lower limit of detection is around 2 at.\%. UV-Visible transmittance spectra are collected by a Perkin-Elmer Lambda 20 spectrometer operating in the range [200-1100] nm. Assuming direct transitions, band-gap values are obtained using the relation:

$$
(\alpha h v)^{2}=\left(h v-E_{g}\right)
$$

where $h v$ is the photon energy. Hence plotting $(\alpha h v)^{2}$ as a function of $h v$, the extrapolation of the linear region at zero gives the value of $E_{g}$. The error is estimated as $0.05 \mathrm{eV}$.

X ray diffractograms are collected using a Seifert XRD 3003 diffractometer with a copper anode. Conventional $\theta-2 \theta$ and $\phi$ scans are recorded. In order to quantify the thin 
film orientation, the Lotgering factor is used. This factor compares the orientation of a thin film versus randomly oriented material (i.e. powder) and is able to vary from 0 for a nonoriented layer to 1 for a total oriented layer. The Lotgering factor is calculated using the relations [32]:

$$
F_{h k l}=\frac{P_{h k l}-P_{0(h k l)}}{1-P_{0(h k l)}}
$$

with $P_{(h k l)}=\frac{\sum_{i} I_{(h k l)}}{\sum_{i} I_{\left(h \prime k^{\prime} \prime l\right)}}$ and $P_{0(h k l)}=\frac{\sum_{i} I_{0(h k l)}}{\sum_{i} I_{0\left(h k^{\prime} / l^{\prime}\right)}}$

where (hkl) is used for the studied orientation of the layer, (h'k'l') are used for the other plane families, $\mathrm{I}(\mathrm{hkl})$ is the intensity of the (hkl) indexed peak and the subscript 0 is relative to the powder reference diffractogram (JCPDS data).

Low frequency dielectric properties are measured at room temperature by a LCR meter (LCR-819 GWInstek) on Metal/Insulator/Metal (MIM) structures. The conducting substrate $\left(\mathrm{Nb}: \mathrm{SrTiO}_{3}\right)$ is used as bottom electrode, whereas $200 \mathrm{~nm}$ sputtered silver serves as the top electrode. Measurements are also done on a dense $\left(\mathrm{Sr}_{0.99} \mathrm{La}_{0.01}\right)_{2}\left(\mathrm{Ta}_{0.99} \mathrm{Ti}_{0.01}\right)_{2} \mathrm{O}_{7}$ ceramic, obtained by uniaxial compaction of oxide powder and sintering at $1540{ }^{\circ} \mathrm{C}$ under air during $2 \mathrm{~h}$, with $200 \mathrm{~nm}$ silver sputtered on both sides of the pellet to achieve a MIM structure.

\section{Results}

Table 1 gathers different characteristics of the as-prepared films, such as their thickness, band gap and Lotgering factor, as well as the reactive $\mathrm{N}_{2} / \mathrm{O}_{2}$ mixtures used for the depositions.

\subsection{Reactive sputtering and deposition rate}

Before the series of deposition, an OES study of the plasma was carried out to investigate the poisoning of the oxide target during reactive sputtering with dioxygen and dinitrogen. Figure 1 presents the evolution of the intensity ratio of the emission peak of 
dinitrogen vs. argon $\left(\mathrm{I}_{\mathrm{N} 2} / \mathrm{I}_{\mathrm{Ar}}\right)$ as a function of sputtering time for a target previously presputtered under dioxygen (vol.\% $\mathrm{O}_{2}=25 /$ vol. $\% \mathrm{~N}_{2}=0$ ) and undergoing a sputtering under dinitrogen (vol. $\% \mathrm{O}_{2}=0 /$ vol. $\% \mathrm{~N}_{2}=25$ ). The onset point corresponds to the changeover from an $\mathrm{Ar} / \mathrm{O}_{2}$ plasma to a $\mathrm{N}_{2}$-containing plasma. A continuous increase of $\mathrm{I}_{\mathrm{N} 2} / \mathrm{I}_{\mathrm{Ar}}$ is observed during the first $60 \mathrm{~min}$ of sputtering, leading to a plateau. Such feature is characteristic of a nitridation of the target: during the first hour of the process, injected $\mathrm{N}_{2}$ is partially consumed in a progressive nitridation of the target surface (and the walls of the deposition chamber), then, a balanced regime is reached. That leads us to choose a sufficient pre-sputtering time of 100 minutes. Furthermore, Figure 1 also demonstrates that the chosen emission of $\mathrm{N}_{2}$ at $357.0 \mathrm{~nm}$ is a valuable parameter to follow the evolution of the reactive sputtering.

Concerning the series of deposition, Figure 2 shows the evolution of the deposition rate as a function of the composition of the deposition plasma (we remind that pre sputtering is performed under the same atmosphere as the deposition). We observe a gradual increase of the deposition rate when the percentage of dinitrogen in the sputtering gas increases, with a greater increase around vol. $\% \mathrm{~N}_{2}=20$. Figure 2 also draws the evolution of the intensity ratio of the emission peak of dinitrogen vs. argon (measured by OES at the end of the presputtering, just before the deposition): the two curves show similar trends, with an inflection point between 15 and 20 vol. $\% \mathrm{~N}_{2}$. These behaviors are relative to the poisoning of the oxide target when sputtered by dinitrogen and will be explained later in the article based upon the results of deposited films.

\subsection{Optical characterization of films}

Transmittance measurements show that films synthetized with dinitrogen ratio between 0 and $24.55 \%$ are transparent in the visible region and lead to band gaps around 4.55 $\mathrm{eV}$, as seen in Table 1 and Supplementary Data 2. The film deposited without oxygen is 
orange and has a band-gap of $2.30 \mathrm{eV}$. These values are in agreement with literature about $\mathrm{Sr}_{2} \mathrm{Ta}_{2} \mathrm{O}_{7}$ and $\mathrm{SrTaO}_{2} \mathrm{~N}$ which leads to band gaps around $4.50-4.60 \mathrm{eV}[33-34]$ and $2.1-2.27$ $\mathrm{eV}[35,25]$, respectively. Furthermore, it can be noted that there is no progressive decrease of the band gap with the increase of dinitrogen ratio in the gas mixture. The sharp drop in the band gap is only obtained for the SLTT- $25_{\mathrm{N} 2}-0_{\mathrm{O} 2}$ sample, for which there is no oxygen in the deposition gas mixture. Such decrease is attributed to substitution of oxygen for nitrogen in the film, thus producing an oxynitride compound. As oxygen is more electronegative than nitrogen, $2 p(\mathrm{~N})$ states will lie above $2 p(\mathrm{O})$ states at the top of the valence band, leading to the observed narrowing of the band-gap for the SLTT- $25_{\mathrm{N} 2}-0_{\mathrm{O} 2}$ sample. EDS characterization confirms the presence of nitrogen only in the SLTT- $25_{\mathrm{N} 2}-0_{\mathrm{O} 2}$ sample.

\subsection{Crystallization of films}

$\theta-2 \theta$ X-ray diffractograms of deposited thin films are shown in Figure 3. Films synthetized with $0 \leq$ vol. $\% \mathrm{~N}_{2} \leq 10$ are clearly indexed as the oxide $\mathrm{Sr}_{2} \mathrm{Ta}_{2} \mathrm{O}_{7}$ (JCPDS 720921) ; a systematic angular deviation with reference is observed. A preferred $<110>$ orientation is visible, quantified by Lotgering factors equal or very close to 1 as shown in Table 1. This preferred orientation has been already reported in the case $\operatorname{of} \mathrm{Sr}_{2} \mathrm{Ta}_{2} \mathrm{O}_{7}$ nanosheets growth [35]. One can detect a limit (vol. $\mathrm{N}_{2}=15 \%$ ) beyond which the crystallinity of samples drastically decreases as reflected by the decline in the intensity of the diffracted peaks as well as falling values of the Lotgering factors. The SLTT- $15_{\mathrm{N} 2}-10_{\mathrm{O} 2}$ film is still referred as the oxide with the appearance of the (151) peak, but, above, the diffracted peaks are better indexed as the oxynitride $\mathrm{SrTaO}_{2} \mathrm{~N}$ compound, with a slight (001) oriented growth. The last sample deposited with vol. $\% \mathrm{~N}_{2}=25$ is highly crystallized, indexed as $\mathrm{SrTaO}_{2} \mathrm{~N}$ with a strong preferred c-axis orientation as proved by its Lotgering factor $\mathrm{F}_{\mathrm{L}}=$ 
0.995. No impurity phases are evidenced, as $\mathrm{SrTa}_{2} \mathrm{O}_{6}$ and $\mathrm{SrTa}_{4} \mathrm{O}_{11}$ detected in the powdered target.

The above results are emphasized in Figure 4 drawing the evolution of the interreticular distances $\left(\mathrm{d}_{\mathrm{hkl}}\right)$ of orientation of films as a function of the percentages of $\mathrm{N}_{2}$ and $\mathrm{O}_{2}$ in the sputtering plasma. The two sets of synthesized films are highlighted: for vol. $\% \mathrm{~N}_{2} \leq 15$, $d_{h k l}$ are assigned to $d_{110}$ of the oxide compound and are close to a value of $3.985 \AA$, whereas above, $\mathrm{d}_{\mathrm{hkl}}$ assigned to $\mathrm{d}_{002}$ of the oxynitride are close to $4.070 \AA$. Values for films are always higher than $\mathrm{Sr}_{2} \mathrm{Ta}_{2} \mathrm{O}_{7}$ and $\mathrm{SrTaO}_{2} \mathrm{~N}$ references on powder. When comparing the distances of the present films deposited on $\mathrm{SrTiO}_{3}(001)$ substrates to those of the twin films deposited on MgO (001) (see Supplementary Data 3), nearly identical $d_{\mathrm{hkl}}$ are obtained despite very different cubic cell parameters for the substrates $\left(\mathrm{c}_{\mathrm{STO}}=3.905 \AA ; \mathrm{c}_{\mathrm{MgO}}=4.211 \AA\right)$. This implies that the films are no longer strained on these substrates due to their high thickness $(\geq$ $665 \mathrm{~nm}$ ); the experimental $\mathrm{d}_{\mathrm{hkl}}$ distances are thus representative of the deposited oxide SLTTO and oxynitride SLTTON thin film materials.

Films deposited at vol\% $\mathrm{N}_{2}=0$ and 25 exhibit a strong preferred orientation, hence epitaxial growth can be expected. $\varphi$ scans, recorded at $\chi=45^{\circ}$ on the (151), (112) and (101) poles of the $\left(\mathrm{Sr}_{0.99} \mathrm{La}_{0.01}\right)_{2}\left(\mathrm{Ta}_{0.99} \mathrm{Ti}_{0.01}\right)_{2} \mathrm{O}_{7}, \quad\left(\mathrm{Sr}_{0.99} \mathrm{La}_{0.01}\right)\left(\mathrm{Ta}_{0.99} \mathrm{Ti}_{0.01}\right) \mathrm{O}_{2} \mathrm{~N}$ and $\mathrm{SrTiO}_{3}$ compounds respectively, are shown in Figure 5. One can see four peaks distanced by $90^{\circ}$. This supports the assumption that the studied compounds can be seen as pseudo-cubic structures, like most of perovskites, because their lattice constant $\mathrm{c}$ is close to $a \sqrt{2}$. The same positions for the film and substrate peaks show an alignment of the film layers with those of substrates in the $\chi=45^{\circ}$ plane. Along with the orientation of films in the $\chi=0^{\circ}$ plane, as observed in Figure 3, this demonstrates the epitaxial growth of the oxide SLTT- $0_{\mathrm{N} 2}-25_{\mathrm{O} 2}$ and oxynitride SLTT- $25_{\mathrm{N} 2}-0_{\mathrm{O} 2}$ samples on $\mathrm{SrTiO}_{3}$ substrate. Nevertheless, the epitaxy for the

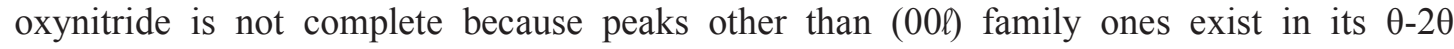


diffractogram. Furthermore, in $\varphi$-scan, the full width at half maximum of the oxynitride film peaks is $\Delta \varphi=6.25^{\circ}$, indicating a substantial dispersion of the crystallographic alignment. This is explained by the relatively high mismatch $(\mathrm{m}=+4.2 \%)$ between the SLTTON film and the $\mathrm{SrTiO}_{3}$ substrate, calculated using the pseudo-cubic parameter of the SLTT- $25_{\mathrm{N} 2}-\mathrm{O}_{\mathrm{O} 2}$ oxynitride film $\left(\mathrm{c}_{\mathrm{PC}-\mathrm{ON}}=4.069 \AA\right)$. For this sample, it is therefore more appropriate to refer to a three-dimensional preferred epitaxy. Furthermore, no lattice tetragonal distortion of the pseudo-cubic cell is revealed here $\left(\mathrm{c}_{\mathrm{PC}-\mathrm{ON}} / \mathrm{a}_{\mathrm{PC}-\mathrm{ON}}=0.996\right)$, as the one emphasized by Oka $e t$ al. on epitaxial $\mathrm{SrTaO}_{2} \mathrm{~N}$ films grown on $\mathrm{SrTiO}_{3}$ substrates [25]. By combining informations from Figures 3 and 5 , the SLTT- $0_{\mathrm{N} 2}-25_{\mathrm{O} 2}$ sample can be considered as fully epitaxially grown. This can be explained by the relatively low mismatch $(\mathrm{m}=+1.9 \%)$ between the SLTTO oxide film, considered as pseudo-cubic $\left(\mathrm{c}_{\mathrm{PC}-\mathrm{O}}=3.978 \AA\right)$, and the $\mathrm{SrTiO}_{3}$ substrate. Nevertheless, in the plane of the sample, the dispersion of the crystallographic alignment between the (151) film plane and (101) substrate plane is high $\left(\Delta \varphi=8.15^{\circ}\right)$, so the epitaxy of the oxide film on the $\mathrm{SrTiO}_{3}$ substrate is qualified as moderate.

\subsection{Dielectric characterization of ceramic and films}

Dielectric properties are measured at $1 \mathrm{kHz}$. This frequency is chosen because, beyond this value, dielectric losses of the oxide materials are too low $\left(\tan \delta<10^{-4}\right)$ and cannot be measured by our experimental setup.

Dielectric measurements performed on the oxide SLTTO ceramic give the following values: permittivity $\kappa_{\text {ceramic }}=54$ and dielectric losses tan $\delta_{\text {ceramic }}<10^{-4}$. This emphasizes moderate permittivity and very low losses.

For the films, the evolution of the permittivity $\kappa$ and loss tangent $\tan \delta$ as a function of the dinitrogen and dioxygen percentages in the sputtering plasma is depicted in Figure 6; values are detailed in Table 2. 
The permittivity values are in the range 39 - 45 for the films deposited with vol. $\% \mathrm{~N}_{2} \leq$ 10. Above this threshold $\mathrm{N}_{2}$ amount, the films permittivity significantly decreases to a minimum of $\kappa=3$ for vol $\% \mathrm{~N}_{2}=23.25$. On the other hand, the film deposited at vol. $\% \mathrm{~N}_{2}=25$ has the highest permittivity $(\kappa=60)$.

Concerning the losses, the lowest values can be obtained for vol. $\% \mathrm{~N}_{2} \leq 15(\tan \delta \sim 3.5$ - $5.010^{-3}$ ); above losses increase up to a tan $\delta$ of $62.510^{-3}$ for vol. $\% \mathrm{~N}_{2}=25$.

\section{Discussion}

All the results of the present study point out a significant change in the reactive sputtering mechanism at a plasma dinitrogen percentage at $15-20$ vol.\%.

The curves presented in Figure 2 both show an inflection point around 15 vol. $\% \mathrm{~N}_{2}$. Up to that threshold, and despite a 100 minutes pre-sputtering time, the $\mathrm{O}_{2} / \mathrm{N}_{2}$ ratio in the reactive gas leads to a partially nitrided target surface. That way, the depositions for vol. $\% \mathrm{~N}_{2} \leq 15$ produce oxide films as underlined by low deposition rates, transparency in visible region, oxide signature in XRD and very low dielectric loss. Plasmas with higher $\mathrm{N}_{2}$ percentages lead to films with an intermediate structure, except for the deposition without dioxygen for which a pure oxynitride film is obtained, with the proper band gap $(2.30 \mathrm{eV})$ and crystallization, and greater dielectric loss. High deposition rates obtained under $\mathrm{N}_{2}$-rich plasma are coherent with a nitrogen enrichment of the target surface during the deposition process ; as a nitrided target shows higher sputtering and secondary electron emitting yields than an oxide target $[36,37]$ deposition rates are here logically higher for oxynitride than for oxide films.

Films deposited with $20 \leq$ vol. $\% \mathrm{~N}_{2} \leq 24.55$ have been characterized by an absorption in the U-V region (with band gaps around $4.55 \mathrm{eV}$ ), no nitrogen detected by EDS, but an oxynitride XRD signature and dielectric losses higher than those of oxide films. These complex films could be considered as mixtures of a small amount of low crystallized 
$\left(\mathrm{Sr}_{0.99} \mathrm{La}_{0.01}\right)_{2}\left(\mathrm{Ta}_{0.99} \mathrm{Ti}_{0.01}\right)_{2} \mathrm{O}_{2} \mathrm{~N}$ oxynitride phase and a high proportion of amorphous $\left(\mathrm{Sr}_{0.99} \mathrm{La}_{0.01}\right)_{2}\left(\mathrm{Ta}_{0.99} \mathrm{Ti}_{0.01}\right)_{2} \mathrm{O}_{7}$ oxide phase conferring them a transparency in the visible range. The presence of the oxynitride phase will explain their increased dielectric losses, as already mentioned for oxynitride ceramics compared to oxide ones [11]. Given the epitaxial "cube on cube" growth for the pure oxide and pure oxynitride films, the low crystallization of these intermediate films could be explained by a difference in the perovskite structure of the compounds. They both belong to the family of tantalum (and titanium) layered perovskite structures described by Lichentberg as $A_{n} B_{n} X_{3 n+2}$ (here, $A=S r, L a ; B=T a, T i$ and $X=O, N$ ) [38]. The $\left(\mathrm{Sr}_{0.99} \mathrm{La}_{0.01}\right)_{2}\left(\mathrm{Ta}_{0.99} \mathrm{Ti}_{0.01}\right)_{2} \mathrm{O}_{7}$ oxide is a $\mathrm{n}=4$ member, made by the stacking of four $(\mathrm{Ta}, \mathrm{Ti}) \mathrm{O}_{6}$ octahedra separated by interlayers containing $\mathrm{Sr}$ (and $\mathrm{La}$ ) and $\mathrm{O}$ atoms. The $\left(\mathrm{Sr}_{0.99} \mathrm{La}_{0.01}\right)_{2}\left(\mathrm{Ta}_{0.99} \mathrm{Ti}_{0.01}\right)_{2} \mathrm{O}_{2} \mathrm{~N}$ oxynitride is relative to $\mathrm{n}=\infty$, with infinite stacking of octahedra in the c direction. These two stacking modes are so different that it could be difficult to stabilize the two structures in one material. In the present study, it was not possible, either in the form of a well-crystallized mixture of phases, nor as a solid solution; can't the amount of nitrogen in films be controlled by this way.

Concerning the dielectric performance of the oxide materials, results obtained on the SLTTO ceramic can be compared to those of the oxide SLTT- $0_{\mathrm{N} 2}-25_{\mathrm{O} 2}$ film. The film permittivity is slightly lower $(\kappa=42)$ than that of the ceramic material $(\kappa=56)$ and the losses are at least higher by one order of magnitude. These values are in the range of those measured on $\mathrm{Sr}_{2} \mathrm{Ta}_{2} \mathrm{O}_{7}$ films ( $\left.\kappa=20-95[22,24]\right)$. The performance gap between ceramic and film is also in agreement with literature reports. Grain size is the key parameter that could affect the dielectric characteristics of films compared with ceramics [39], because smaller grains in films induce more grain-boundary dead layers leading to a low permittivity. Here, as measured by SEM (Figure 7), the grain size is estimated at $\phi \sim 100 \mathrm{~nm}$ for the film and is in the range $1-10 \mu \mathrm{m}$ for the ceramic. 
For the series of films, characterizations show that the quality of crystallization is correlated with permittivity values: high values are obtained for the fully or preferentially epitaxial films (SLTT- $0_{\mathrm{N} 2}-25_{\mathrm{O} 2}$ and SLTT- $25_{\mathrm{N} 2}-0_{\mathrm{O} 2}$ ), whereas low $\kappa$ values are obtained for the poor crystallized intermediate films.

For the oxynitride SLTT- $25_{\mathrm{N} 2}-0_{\mathrm{O} 2}$ film, the permittivity value $(60)$ is close to the values reported on $\mathrm{SrTaO}_{2} \mathrm{~N}$ ceramics obtained by high pressing sintering [13] which range from 60 to $200(@ 100 \mathrm{kHz})$ with losses tan $\delta>0.1$. At the contrary, our results are very far from those published on a $\mathrm{SrTaO}_{2} \mathrm{~N}$ film [25], with a permittivity value above 2000 at $1 \mathrm{kHz}$ (RT). This film, with thickness $288 \mathrm{~nm}$, shows a tetragonal distortion, leading to a model based on a trans-type $\mathrm{N}$ ordering in small domains, thus exhibiting a classical ferroelectric behavior and high permittivity. In our study, the oxynitride film is perfectly relaxed because of its high thickness which can hide the high permittivity contribution of the first strained layers. Future work on the influence of thickness on the dielectric characteristics of oxynitride films will highlight this point.

Finally, our study shows that the dielectric characterization, beyond giving values to evaluate the integration of films in electronic and telecommunication devices, act as a complementary characterization of compounds containing nitrogen and can be as (more) sensitive than other methods.

\section{Conclusion}

$\left(\mathrm{Sr}_{0.99} \mathrm{La}_{0.01}\right)_{2}\left(\mathrm{Ta}_{0.99} \mathrm{Ti}_{0.01}\right)_{2} \mathrm{O}_{7}$ oxide and $\left(\mathrm{Sr}_{0.99} \mathrm{La}_{0.01}\right)_{2}\left(\mathrm{Ta}_{0.99} \mathrm{Ti}_{0.01}\right)_{2} \mathrm{O}_{2} \mathrm{~N}$ oxynitride are related to the solid solution between the ferroelectric $\mathrm{Sr}_{2} \mathrm{Ta}_{2} \mathrm{O}_{7}$ and $\mathrm{La}_{2} \mathrm{Ti}_{2} \mathrm{O}_{7}$ perovskite compounds. They were synthesized as thin films by magnetron rf sputtering using an oxide target under a reactive gas composed of dioxygen and dinitrogen with percentages varying inversely from 0 to 25 . Different kinds of films were obtained. For $0 \leq$ vol. $\% \mathrm{~N}_{2} \leq 15$, the 
films are assigned to the $\left(\mathrm{Sr}_{0.99} \mathrm{La}_{0.01}\right)_{2}\left(\mathrm{Ta}_{0.99} \mathrm{Ti}_{0.01}\right)_{2} \mathrm{O}_{7}$ oxide isostructural to the $\mathrm{Sr}_{2} \mathrm{Ta}_{2} \mathrm{O}_{7}$ material, with a band-gap close to $4.55 \mathrm{eV}$. The films are epitaxially grown or (110) oriented on (001) $\mathrm{SrTiO}_{3}$ substrates. Their permittivities are in the range of $\kappa=45-25 @ 1 \mathrm{kHz}$ with values decreasing when the percentage of dinitrogen in plasma grows; the dielectric losses are inferior to $5.10^{-3}$. For vol. $\% \mathrm{~N}_{2}=25$, the film corresponds to the $\left(\mathrm{Sr}_{0.99} \mathrm{La}_{0.01}\right)\left(\mathrm{Ta}_{0.99} \mathrm{Ti}_{0.01}\right) \mathrm{O}_{2} \mathrm{~N}$ oxynitride, isostructural to $\mathrm{SrTaO}_{2} \mathrm{~N}$, with a band gap of $2.30 \mathrm{eV}$. It is preferentially $3 \mathrm{D}$ epitaxially grown on (001) $\mathrm{SrTiO}_{3}$ substrate. Its permittivity is the highest of the series of depositions ( $\kappa=60 @ 1 \mathrm{kHz})$, as well as its dielectric losses $\left(62.5 \cdot 10^{-3}\right)$. In between, that is for $20 \leq$ vol. $\% \mathrm{~N}_{2} \leq 24.55$, the films are poorly crystallized with an oxynitride contribution and could correspond to mixtures of the oxide and the oxynitride phases. The permittivities are low $(\kappa=18.5-2.5)$ and their increasing dielectric losses could be explained by the oxynitride contribution. Finally, SLTTO oxide films, with very small tan $\delta$ values and relatively high permittivities, could be used as low dielectric loss material in electronic and telecommunication devices.

\section{Acknowledgments}

The authors gratefully acknowledge C. Cardinaud and P-Y. Tessier from the Institute of Materials Jean Rouxel (UMR 6502), Nantes, France, for providing the Optical Emission Spectrometer.

\section{References}

[1] K.K. Mauryaa, S.K. Haldera, S. Senb, A. Boseb, S. Bysakhb, High resolution X-ray and electron microscopy characterization of PZT thin films prepared by RF magnetron sputtering, Appl. Surf. Sci. 313 (2014) 196-206. 
[2] K. Nadaud, C. Borderon, H. Gundel, S. Pavy, Realization and characterization of manganese doped BST thin films for reflectarray applications, IEEE International Symposium on the Applications of Ferroelectrics, Jul 2013, Prague, Czech Republic. pp.145-148.

[3] Y. Corredores, A. Le Febvrier, X. Castel, R. Sauleau, R. Benzerga, S. Députier, M. Guilloux-Viry, A. Mekadmini, N. Martin, G. Tanné, Study of ferroelectric/dielectric multilayers for tunable stub resonator applications at microwaves, Thin Solid Films 553 (2014) 109-113.

[4] S. Gevorgian, A. Vorobiev, A. Deleniv, Ferroelectrics in microwave devices, circuits and systems physics, modeling, fabrication and measurements, in Engineering Materials and Processes; Springer: London, 2009; pp 61-113.

[5] H. V. Nguyen, R. Benzerga, C. Borderon, C. Delaveaud, A. Sharaiha, R. Renoud, C.Le Paven, S. Pavy, K. Nadaud, H. W. Gundel, Miniaturized and reconfigurable notch antenna based on a BST ferroelectric thin film, Mater. Res. Bull. 67 (2015) 255-260.

[6] H. Nguyen, R. Benzerga, C. Delaveaud, C. Le Paven, Y. Lu, A. Sharaiha, L. Le Gendre, S. Députier, F. Tessier, F. Cheviré, X. Castel, Miniaturized notch antenna based on lanthanum titanium perovskite oxide thin films, Thin Solid Films 563(2014) 36-39.

[7] S. Nanamatsu, M. Kimura, K. Doi, S.Matsushita, N. Yamada, A new ferroelectric: $\mathrm{La}_{2} \mathrm{Ti}_{2} \mathrm{O}_{7}$, Ferroelectrics 8 (1974) 511-513.

[8] H. Yan, H. Ning, Y. Kan, P. Wang, M.J. Reece, Piezoelectric ceramics with super-high Curie points, J. Am. Ceram. Soc. 92 (2009) 2270-2275.

[9] K. Maeda, (Oxy)nitrides with d0-electronic configuration as photocatalysts and photoanodes that operate under a wide range of visible light for overall water splitting, Phys. Chem. Chem. Phys. 15 (2013) 10537-10548.

[10] A.E. Maegli, S. Pokrant, T. Hisatomi, M. Trottmann, K. Domen, A. Weidenkaff, Enhancement of photocatalytic water oxidation by the morphological control of $\mathrm{LaTiO}_{2} \mathrm{~N}$ and cobalt oxide catalysts, J. Phys. Chem. C 2014, 118 (30), 16344-16351.

[11] Y. I. Kim, P.M. Woodward, K.Z. Baba-Kishi, C.W. Tai, Characterization of the structural, optical, and dielectric properties of oxynitride perovskites $\mathrm{AMO}_{2} \mathrm{~N}(\mathrm{~A}=\mathrm{Ba}, \mathrm{Sr}$, $\mathrm{Ca} ; \mathrm{M}=\mathrm{Ta}, \mathrm{Nb}$ ), Chem. Mater. 16 (2004) 1267-1276.

[12] Y. Hinuma, H. Moriwake, Y.-R. Zhang, T. Motohashi, S. Kikkawa, I. Tanaka, Firstprinciples study on relaxor-type ferroelectric behavior without chemical inhomogeneity in $\mathrm{BaTaO}_{2} \mathrm{~N}$ and $\mathrm{SrTaO}_{2} \mathrm{~N}$, Chem. Mater. 24 (2012) 4343-4349. 
[13] Y. Masubuchi, F. Kawamura, T. Taniguchi, S. Kikkawa, High pressure densification and dielectric properties of perovskite-typeoxynitride $\mathrm{SrTaO}_{2} \mathrm{~N}$, J. Eur. Ceram. Soc. 35 (2015) 1191-1197.

[14] L. Clark, J. Oro-Sole, K.S. Knight, A. Fuertes, J.P. Attfield, Thermally robust anionchain order in oxynitride perovskites, Chem. Mater. 25 (2013) 5004-5011.

[15] Y. I. Kim, W. Si, P. M. Woodward, E. Sutter, S. Park, T. Vogt, Epitaxial thin-film deposition and dielectric properties of the perovskite oxynitride $\mathrm{BaTaO}_{2} \mathrm{~N}$, Chem. Mater. 19 (2007) 618-623.

[16] R. Aguiar, A. Weidenkaff, C. W. Schneider, A. Reller, S. G. Ebbinghaus, Synthesis and properties of oxynitrides ( $\mathrm{La}, \mathrm{Sr}) \mathrm{Ti}(\mathrm{O}, \mathrm{N})_{3}$ thin films, Prog. Solid State Chem. 35 (2007) 291-298.

[17] I. Marozau, A. Shkabko, M. Döbeli, T. Lippert, M. Mallepell, C. W. Schneider, A. Weidenkaff, A. Wokaun, Pulsed laser deposition and characterisation of perovskite-type $\mathrm{LaTiO}_{3 \mathrm{x}} \mathrm{N}_{\mathrm{x}}$ thin films, Acta Mater. 59 (2011) 7145-7154.

[18] C. Le Paven, L. Le Gendre, R. Benzerga, F. Cheviré, F. Tessier, S. Jacq, S. TraoréMantion, A. Sharaiha, Growth of ( $\mathrm{Sr}, \mathrm{La})-(\mathrm{Ta}, \mathrm{Ti})-\mathrm{O}-\mathrm{N}$ perovskite oxide and oxynitride films by radio frequency magnetron sputtering: influence of the reactive atmosphere on the film structure, J. Cryst. Growth, 413 (2015) 5-11.

[19] F. Tessier, L. Le Gendre, F. Chevire, R. Marchand, A. Navrotsky, Thermochemistry of a new class of materials containing dinitrogen pairs in an oxide matrix, Chem. Mater. 17 (2005) 3570-3574.

[20] K-F. Chiu, S-H. Su, H-J. Leu, C-H. Hsia, Titanium oxynitride thin films as high-capacity and high-rate anode materials for lithium-ion batteries, Thin Solid Films (2015), doi10.1016/j.tsf.2015.09.083

[21] Y. Guo, S. Kikkawa, The electrical conductivity of the oxynitride $\mathrm{Li}_{2.3}\left(\mathrm{O}_{0.7} \mathrm{~N}_{0.3}\right)$ obtained from the high temperature oxidation of $\mathrm{Li}_{3} \mathrm{~N}$, Solid State Ionics (2015), doi 10.1016/j.ssi.2015.08.006

[22] K. Kato, Surface morphology and dielectric properties of alkoxy-derived $\mathrm{Sr}_{2} \mathrm{Ta}_{2} \mathrm{O}_{7}$ and $\mathrm{Sr}_{2}(\mathrm{Ta}, \mathrm{Nb})_{2} \mathrm{O}_{7}$ thin films, J. Mater. Sci. Mater. Electr. 11 (2000) 575-578.

[23] C.Y. Kim, C.Y. Koo, D.C. Woo, H.Y. Lee, Ferroelectric $\mathrm{Sr}_{2}(\mathrm{Nb}, \mathrm{Ta})_{2} \mathrm{O}_{7}$ thin films prepared by chemical solution, Jpn. J. Appl. Phys. 39 (2000) 5521-5524. 
[24] M. Lukosius, C. Wenger, S. Pasko, I. Costina, J. Dabrowski, R. Sorge, H.-J. Müssig, C. Lohe, Atomic vapour deposition of strontium tantalates films for MIM applications, IEEE Trans. Electr. Devices 55 (2008) 2273-2277.

[25] D. Oka,Y. Hirose, H. Kamisaka, T. Fukumura, K. Sasa, S. Ishii, H. Matsuzaki, Y. Sato, Y. Ikuhara, T. Hasegawa, Possible ferroelectricity in perovskite oxynitride $\mathrm{SrTaO}_{2} \mathrm{~N}$ epitaxial thin films, Sci. Rep. 4 (2014) 4987.

[26] A. Ziani, C. Le Paven-Thivet, L. Le Gendre, D. Fasquelle, J.C. Carru, F. Tessier, J. Pinel, Structural and dielectric properties of oxynitride perovskite $\mathrm{LaTiO}_{\mathrm{x}} \mathrm{N}_{\mathrm{y}}$ thin films, Thin Solid Films 517 (2008) 544-549.

[27] Y. Lu, C. Le Paven, H. V. Nguyen, R. Benzerga, L. Le Gendre, S. Rioual, F. Tessier, F. Chevire', A. Sharaiha, C. Delaveaud, X. Castel, Reactive sputtering deposition of perovskite oxide and oxynitride lanthanum titanium films: structural and dielectric characterization, Crys. Growth Design 13 (2013) 4852-4858.

[28] P.A. Fuierer, R.E. Newham, $\mathrm{La}_{2} \mathrm{Ti}_{2} \mathrm{O}_{7}$ ceramics, J. Am. Ceram. Soc. 74 (1991) 2876.

[29] D. Fasquelle, J.C. Carru, L. Le Gendre, C. Le Paven, J. Pinel, F. Cheviré, F. Tessier, R.

Marchand, Lanthanum titanate ceramics: electrical characterizations in large temperature and frequency ranges, J. Eur. Ceram. Soc. 25 (2005) 2085-2088.

[30] "NIST Atomic Spectra Database" National Institute of Standards and Technology, Gaithersburg, MD. [Online]. Available: http://physics.nist.gov/asd.

[31] R. W. B. Pearse and A. G. Gaydon, The identification of molecular spectra, Fourth Edition. Chapman and Hall, 1976, p. 407.

[32] F.K. Lotgering, Topotactical reactions with ferromagnetic oxides having hexagonal crystal structures, J. Inorg. Nucl. Chem 9 (1959) 113-123.

[33] Y. Mizuno, H. Wagata, K. Yubuta, N. Zettsu, S. Oishi, K. Teshima, Flux growth of $\mathrm{Sr}_{2} \mathrm{Ta}_{2} \mathrm{O}_{7}$ crystals and subsequent nitridation to form $\mathrm{SrTaO}_{2} \mathrm{~N}$ crystals, Cryst. Eng. Comm. 15 (2013) 8133-8138.

[34] O. Fursenko, J. Bauer, G. Lupina, P. Dudek, M. Lukosius, C. Wenger, P. Zaumseil, Optical properties and band gap characterization of high dielectric constant oxides, Thin Solid Films 520 (2012) 4532-4535.

[35] C. Zhou, G. Chen, Y. Li, H. Zhang, J. Pei, Photocatalytic activities of $\operatorname{Sr}_{2} \mathrm{Ta}_{2} \mathrm{O}_{7}$ nanosheets synthesized by a hydrothermal method, Int. J. H. Energy 34 (2009) 2113 - 2120.

[36] D.H. Kim, G.H. Lee, S.Y. Lee, D.H. Kim, Atomic scale simulation of physical sputtering of silicon oxide and silicon nitride thin films, J.Cryst.Growth 286 (2006) 71-77. 
[37] D. Depla, X.Y. Li, S. Mahieu, R. De Gryse, Determination of the effective electron emission yields of compound materials, J. Phys. D:Appl. Phys 41 (2008) 202003-202007.

[38] F. Lichtenberg, A. Herrnberger, K. Wiedenmann, J. Mannhart, Synthesis of related layered $\mathrm{A}_{\mathrm{n}} \mathrm{B}_{\mathrm{n}} \mathrm{O}_{3 \mathrm{n}+2}=\mathrm{ABO}_{\mathrm{x}}$ type niobates and titanates and their structural, electric and magnetic properties, Prog. Solid State Chem. 29 (2001) 1-70.

[39] J. Petzelt, S. Kamba, J. Hlinka, Ferroelectric soft modes in ceramics and films, in New developments in advanced functional ceramics. Ed. L. Mitoseriu, Indian Series of Appl. Phys., Transworld Research Network 37/661, Trivandrum,.Kerala, India, pp. 387-421 (2007). 
Table 1.

List of films deposited by reactive rf sputtering from a $\left(\mathrm{Sr}_{0.99}, \mathrm{La}_{0.01}\right)_{2}\left(\mathrm{Ta}_{0.99}, \mathrm{Ti}_{0.01}\right)_{2} \mathrm{O}_{7}$ target on $\mathrm{MgO}$ and $\mathrm{Nb}-\mathrm{SrTiO}_{3}$ substrates, along with their thickness, band-gap and Lotgering factor. The samples are labelled as SLTT- $\mathrm{X}_{\mathrm{N2}}-\mathrm{Y}_{\mathrm{O} 2}$, with $\mathrm{x}$ the percentage of $\mathrm{N}_{2}$ and $y$ the percentage of $\mathrm{O}_{2}$ in the sputtering plasma.

\begin{tabular}{|c|c|c|c|c|c|}
\hline Sample & \%vol. $\mathrm{N}_{2}$ & $\%$ vol. $\mathrm{O}_{2}$ & $\begin{array}{c}\text { Thickness } \\
\text { (nm) }\end{array}$ & $\begin{array}{c}\text { Band gap } \\
(\mathrm{eV})\end{array}$ & $\begin{array}{l}\text { Lotgering } \\
\text { Factor } F_{L}\end{array}$ \\
\hline SLTT- $0_{\mathrm{N} 2}-25_{\mathrm{O} 2}$ & 0 & 25 & 775 & 4.60 & 1 \\
\hline SLTT- $2.5_{\mathrm{N} 2}-22.5_{\mathrm{O} 2}$ & 2.5 & 22.5 & 870 & 4.45 & 1 \\
\hline SLTT- $5_{\mathrm{N} 2}-20_{\mathrm{O} 2}$ & 5 & 20 & 700 & 4.65 & 1 \\
\hline SLTT $-10_{\mathrm{N} 2}-15_{\mathrm{O} 2}$ & 10 & 15 & 830 & 4.40 & 0.995 \\
\hline SLTT $-15_{\mathrm{N} 2}-10_{\mathrm{O} 2}$ & 15 & 10 & 665 & 4.45 & 0.635 \\
\hline SLTT $-20_{\mathrm{N} 2}-5_{\mathrm{O} 2}$ & 20 & 5 & 775 & 4.60 & 0.805 \\
\hline SLTT $-22.5_{\mathrm{N} 2}-2.5_{\mathrm{O} 2}$ & 22.5 & 2.5 & 735 & 4.70 & 0.875 \\
\hline SLTT- $23.25_{\mathrm{N} 2}-1.75_{\mathrm{O} 2}$ & 23.25 & 1.75 & 770 & 4.60 & 0.745 \\
\hline SLTT- $24.55_{\mathrm{N} 2}-0.45_{\mathrm{O} 2}$ & 24.55 & 0.45 & 885 & 4.65 & 0.720 \\
\hline SLTT- $25_{\mathrm{N} 2}-0_{\mathrm{O} 2}$ & 25 & 0 & 1120 & 2.30 & 0.995 \\
\hline
\end{tabular}


Table 2.

Permittivity Kand loss tangent tan $\delta$ at $1 \mathrm{kHz}$ of the oxide ceramic and SLTT films labelled as $S L T T-x_{N 2}-y_{O 2}$, with $x$ the percentage of $N_{2}$ and $y$ the percentage of $\mathrm{O}_{2}$ in the sputtering plasma.

\begin{tabular}{|c|c|c|}
\hline Sample & к (@1kHz) & $\tan \delta(@ 1 \mathrm{kHz})$ \\
\hline SLTT- $0_{\mathrm{N} 2}-25_{\mathrm{O} 2}$ & 42 & $3.510^{-3}$ \\
\hline SLTT $-2.5_{\mathrm{N} 2}-22.5_{\mathrm{O} 2}$ & 45 & $4.010^{-3}$ \\
\hline SLTT- $5_{\mathrm{N} 2}-20_{\mathrm{O} 2}$ & 41 & $5.010^{-3}$ \\
\hline SLTT $-10_{\mathrm{N} 2}-15_{\mathrm{O} 2}$ & 39 & $3.510^{-3}$ \\
\hline SLTT $-15_{\mathrm{N} 2}-10_{\mathrm{O} 2}$ & 25 & $4.010^{-3}$ \\
\hline SLTT $-20_{\mathrm{N} 2}-5_{\mathrm{O} 2}$ & 19 & $15.510^{-3}$ \\
\hline SLTT $-22.5_{\mathrm{N} 2}-2.5_{\mathrm{O} 2}$ & 5 & $35.010^{-3}$ \\
\hline SLTT- $23.25_{\mathrm{N} 2}-1.75_{\mathrm{O} 2}$ & 3 & $30.510^{-3}$ \\
\hline SLTT- $24.55_{\mathrm{N} 2}-0.45_{\mathrm{O} 2}$ & 3 & $24.510^{-3}$ \\
\hline SLTT $-25_{\mathrm{N} 2}-0_{\mathrm{O} 2}$ & 60 & $62.510^{-3}$ \\
\hline SLTTO ceramic & 54 & $<10^{-4}$ \\
\hline
\end{tabular}


Figure Captions

Figure 1. Evolution of the intensity ratio of the emission peak of dinitrogen vs. argon $\left(\mathrm{I}_{\mathrm{N} 2} /\right.$ $\mathrm{I}_{\mathrm{Ar}}$ ) recorded by OES as a function of reactive sputtering time, with a plasma containing 75 vol.\% $\mathrm{Ar}$ and 25 vol.\% $\mathrm{N}_{2}$ and a target initially oxidized (pre-sputtered with $75 \mathrm{vol} . \% \mathrm{Ar}$ and 25 vol. $\left.\% \mathrm{O}_{2}\right)$.

Figure 2. Evolution of the deposition rate of SLTT films and the ratio of emitted intensities recorded by OES as a function of dinitrogen and dioxygen percentages in the reactive sputtering plasma.

Figure 3. $\theta-2 \theta$ X-ray diffractograms of SLTT thin films deposited on $\mathrm{Nb}: \mathrm{SrTiO}_{3}(001)$ (STO) substrates labelled as SLTT- $\mathrm{x}_{\mathrm{N} 2}-\mathrm{y}_{\mathrm{O} 2}$, with $\mathrm{x}$ the percentage of $\mathrm{N}_{2}$ and $\mathrm{y}$ the percentage of $\mathrm{O}_{2}$ in the sputtering plasma (dotted lines underline some peaks indexed as an oxynitride; solid lines underline some peaks indexed as an oxide).

Figure 4. Calculated inter-reticular $\mathrm{d}_{\mathrm{hkl}}$ distances of orientation of SLTT films as a function of the dinitrogen and dioxygen percentages in the reactive sputtering plasma. Dotted line draws tabulated values of $\mathrm{SrTaO}_{2} \mathrm{~N}\left(\mathrm{~d}_{002}\right)$ and solid line tabulated values of $\operatorname{Sr}_{2} \mathrm{Ta}_{2} \mathrm{O}_{7}\left(\mathrm{~d}_{110}\right)$. The error bar is less than the symbol size.

Figure 5. X-ray diffraction $\varphi$ scans at $\chi=45^{\circ}$ of: (a) the film deposited without dinitrogen (SLTT- $0_{\mathrm{N} 2}-25_{\mathrm{O} 2}$, pole (151) and its $\mathrm{SrTiO}_{3}$ substrate (pole (101), (b) the film deposited without dioxygen (SLTT-25 $5_{\mathrm{N} 2}-0_{\mathrm{O} 2}$, pole (112) and its $\mathrm{SrTiO}_{3}$ substrate (pole (101)).

Figure 6. Evolution of the permittivity $\kappa$ and loss tangent tan $\delta$ of SLTT films as a function of the dinitrogen and dioxygen percentages in the reactive sputtering plasma (the error bar is the symbol size).

Figure 7. Surface morphology seen by scanning electron microscopy of the $\left(\mathrm{Sr}_{0.99} \mathrm{La}_{0.01}\right)_{2}\left(\mathrm{Ta}_{0.99} \mathrm{Ti}_{0.01}\right)_{2} \mathrm{O}_{7}$ material as (a) thin film (SLTT- $0_{\mathrm{N} 2}-25_{\mathrm{O} 2}$ sample) and (b) ceramic (the magnifications are different because of dissimilar grain sizes). 

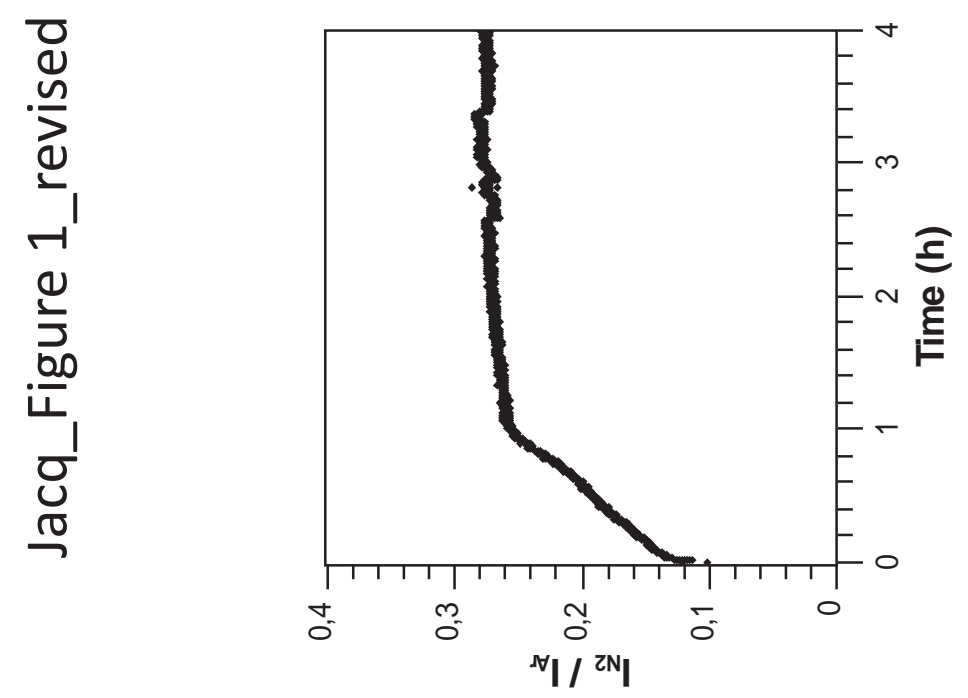


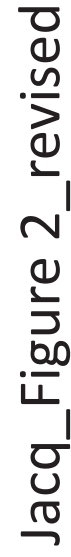

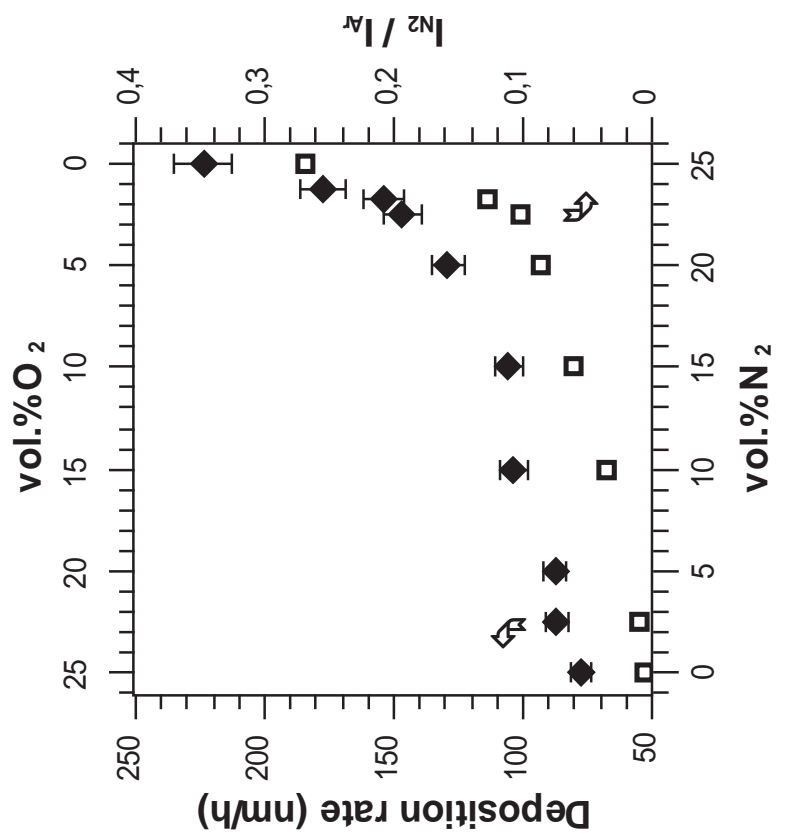




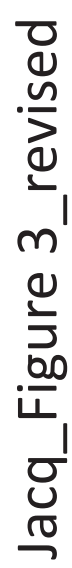

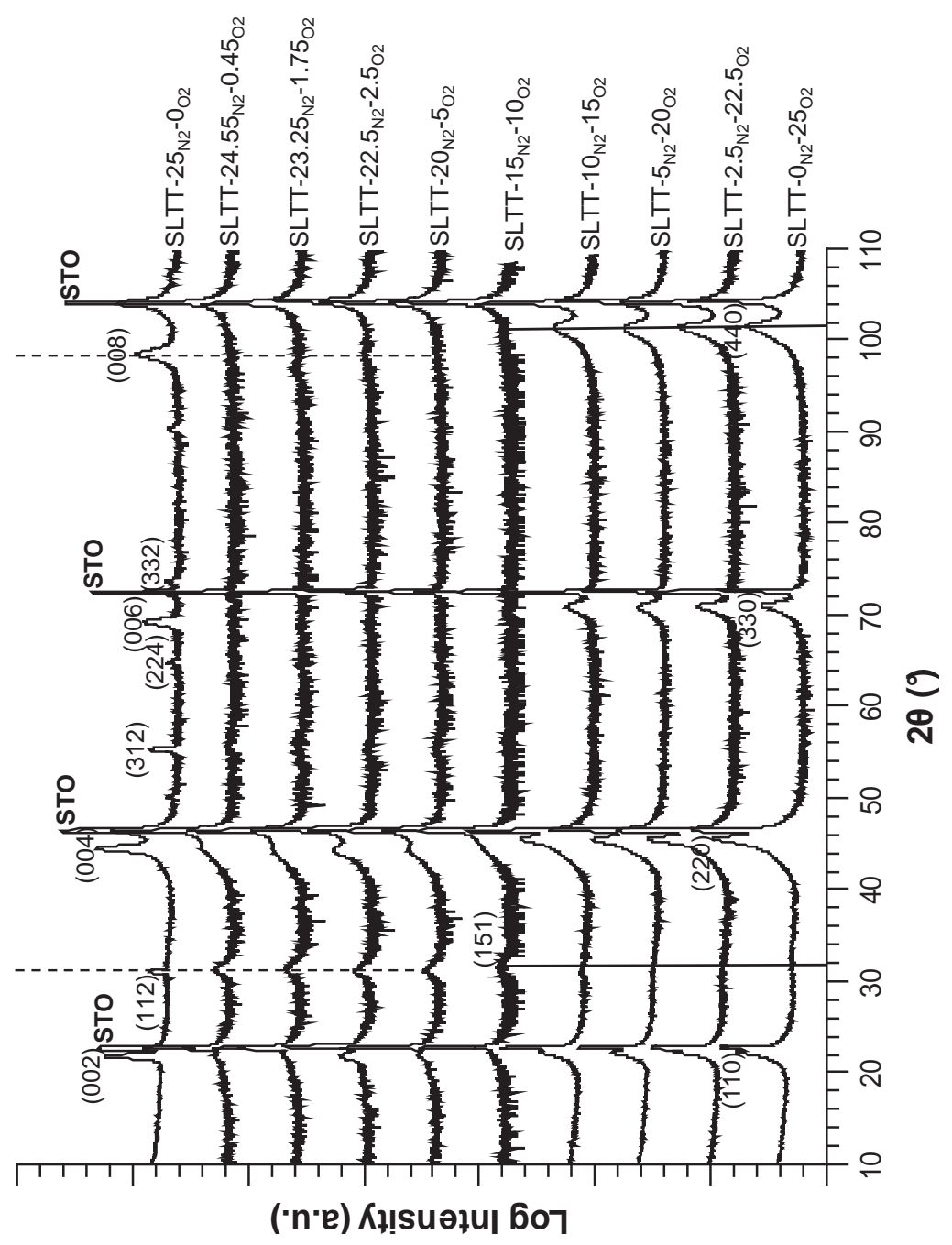




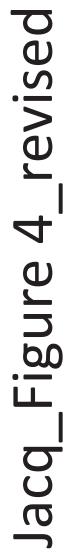

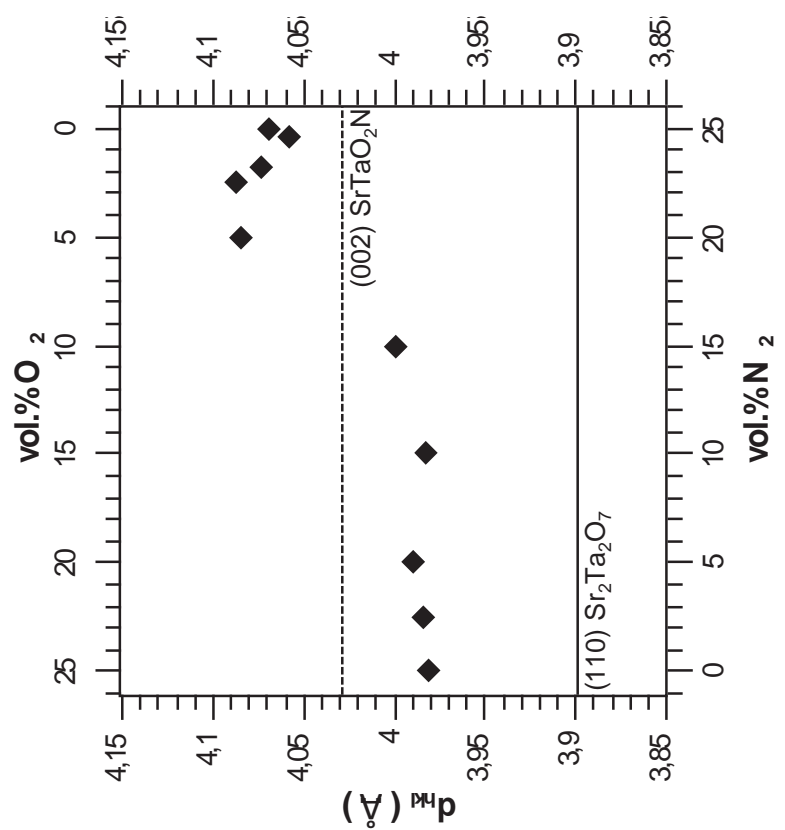



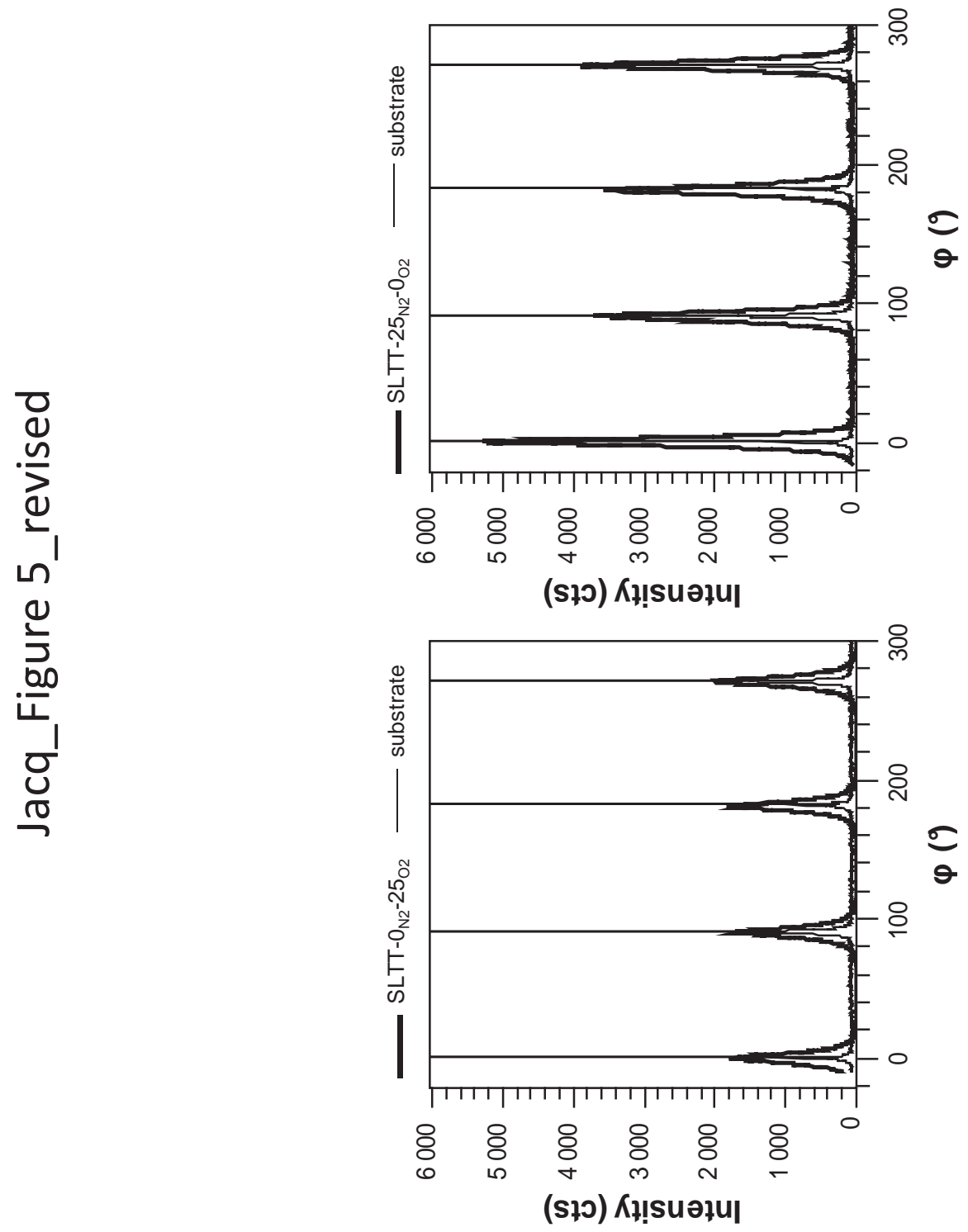


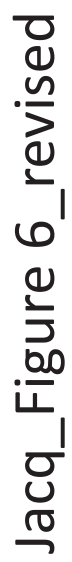

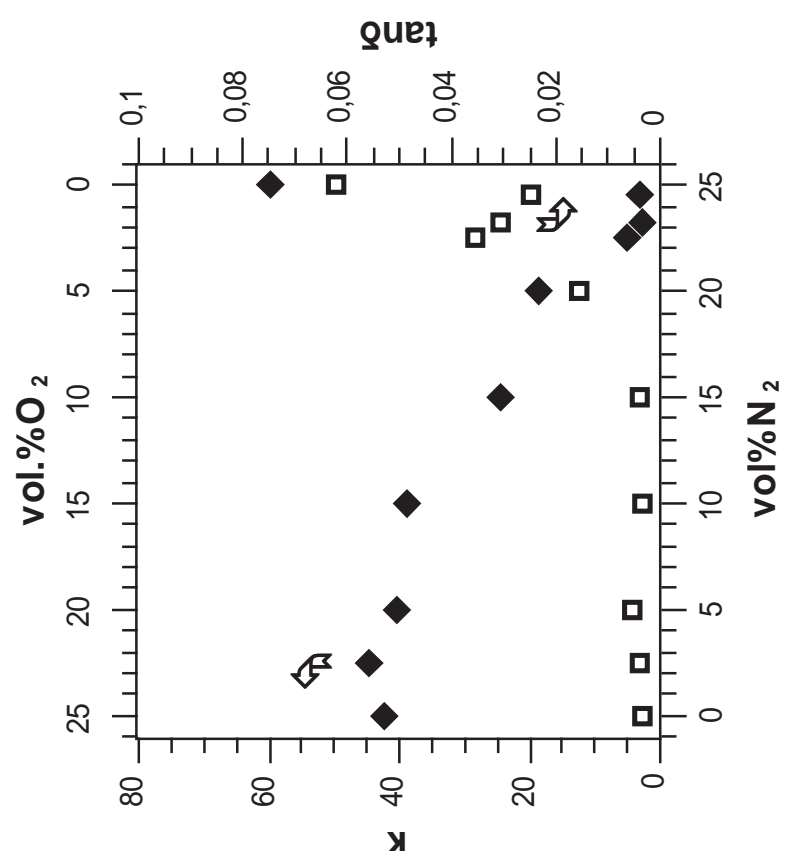




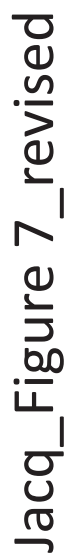
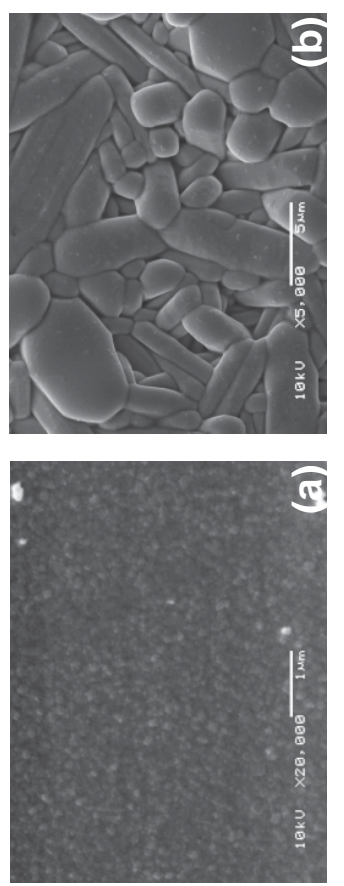